\title{
AGRICULTURE, LANDSCAPE AND HUMAN IMPACT IN SOME KARST AREAS OF ITALY
}

\author{
Ezio Burri, Benedetta Castiglioni and Ugo Sauro(1)
}

\section{Introduction}

Italy is made up for about $1 / 5$ of its surface by soluble rocks, which represent the arena of karst environments. The karst morpho-units, some hundreds, are mainly distributed inside the alpine structure of the Mediterranean mountains. A very large number of rock formations are present, different in facies, lithology, age, etc. Among these, carbonate rocks prevail, followed by gypsum and salt. Most of the carbonate rocks are limestones sedimented in a platform environment and they show a wide range of porosity, frequency of fractures and bedding planes.

Many of the mountain groups result from still-active tectonics and their recent morphodynamic evolution has been characterised by wide climatic and environmental changes. The parent materials of the soils of these karst areas are of many different types: insoluble residues of solutional processes, loess-like and dune-like eolic deposits, volcanic ashes, transgressive coastal sediments and different mixtures of the above-mentioned materials and/or colluvia of older soil covers. According to the climatic regimes, thick colluvial deposits have been accumulated in some karst depressions, resulting from the deposition of soil sediments and other materials from the slopes.

The climatic processes, the expression of some different sub-types of Mediterranean climate (from the typical Mediterranean to sub-atlantic and sub-continental varieties), are the main control of the recent morphodynamics inside the karst morpho-units.

In some areas the variability of precipitation is very high. The soil-water deficit during summer, together with the steep slopes, makes these environments highly vulnerable to human impact, especially in relation to soil use for grazing and agriculture.

The soils, with enriched mineral contents from the fall of loess-like sediments or of volcanic ashes, were surely very appealing to the first farmers.

\section{Man and the karst areas}

The first settlers of the Italian karst areas were Palaeolithic hunters, who utilised the natural shelters and the chert as raw material for the making of stone tools. In the

\footnotetext{
(1) The paper is the result of the cooperation of all the Authors. In particular the general parts are the result of a common discussion. Paragraphs $n^{\circ} 6$ is written by E. Burri, par. $n^{\circ} 8$ by $B$. Castiglioni, the others by U. Sauro.
} 
Lamalunga Cave in southern Italy a complete skeleton of a pre-Neandertal man has been discovered.

The Lessini Mountains in the Venetian Pre-Alps and the Gargano promontory in Puglia are the Italian karst areas richest in good quality chert nodules and lenses. The chert resources of the Lessini Mountains have been exploited since the XIX century for the production of flints.

The first farming was established during the early Neolithic, about 7000 years B.P., as a result of the settlement of groups migrating from eastern countries and of their cultural transmission. Thereafter, forest clearing spread in order to claim land for agriculture and grazing. In the areas with a soil-water deficit, the deforestation and clearing of pastures were often achieved with fire.

The environments most vulnerable to human impact were both the Mediterranean woodland and the boreal mountain belt utilised for summer grazing and, during the first phases, also for hunting. The beech forest belt, a more stable environment less subject to fires, survived until the Middle Ages, when the increasing demand of towns for charcoal drove the mountaineers to exploit this important reservoir of wood. In his poem "The Divine Comedy", Dante Alighieri drew inspiration from the beech forest to depict his "gloomy wood": "Mi ritrovai in una selva oscura, che la retta via era smarrita" (I found me in a gloomy wood, astray / Gone from the path direct...).

\section{Resource use and land reclamation}

Traditional agriculture and sheep rearing were, until World War II, closely linked with the use of other environmental resources within an economy of mainly self-consumption and the exchange of a few products.

Forestry, the working of chert for the manufacture, trade of stone tools during protohistorical times and of flints during historical times, and quarrying activities for building and lime production were closely linked with farming.

After the forest clearing, the land use for agriculture needed continuous work for the maintenance of soil productivity, such as the removal of stones. The stone clearing in fields and pastures continued in time, due to the outcropping of rocks following soil erosion.

The problems of water scarcity were partially solved by excavating closed basins and tanks and waterproofing them with clay to store runoff water from the surrounding slopes and roofs of buildings.

The man-environment relationships, aimed at the optimal use of natural resources, have been expressed as strategies that have led to the creation of characteristic landscapes, rich in signs of human activities.

A distinctive character of karst agricultural landscapes is the subdivision into many small plots of land adapted to the peculiar landforms of the karst surface and marked by different types of land use, according to the productivity of the soils and the local microclimatic conditions. Some authors have applied to these landscapes 
the term "oasised" agriculture. This oasisation is linked to the soil thickness, which depends on the topography. The soil is thicker on the bottom of closed karst depressions, such as dolines and poljes.

In the karst massifs of the central and southern Apennines, there is a great variety of examples of adaptation of agricultural plots to the various karst forms. The different land uses depend on the types, sizes and elevations of the karst forms. In particular:

a) broad karst plains surrounded by steep slopes, at high and medium altitude, are essentially used for collateral grazing activities; the presence of temporary ponds also permits the watering of livestock in summer. However, often if there are few animals or if they are directed elsewhere, the luxuriant vegetation is cut and used as forage; examples of these forms are in Marche (Montelago), Umbria (Colfiorito and Piangrande), Lazio (Rascino), Abruzzo (Campo Imperatore, Voltigno, Piano Cinquemiglia, Piano delle Rocche, Quarto Grande, Barone and S. Chiara), Molise (Civitanova) and Basilicata (Galdo, Rotonda);

b) smaller karst plains at medium altitude are in part still used for cultivation; sometimes the internal surface, delineated by the edge of the depression, is divided into long narrow cultivated fields crossed by a road used for the transit of wagons; this is a very ancient practice, preserved still today, to permit all the landowners easy and equal access and to allow easier crop rotation; a careful clearing of stones is performed inside the karst forms and the resulting detritus is collected in piles or it is used to build dry walls for protection, enclosures or terrace support; typical examples are located on the western slope of the Gran Sasso d'Italia (fig. 1);

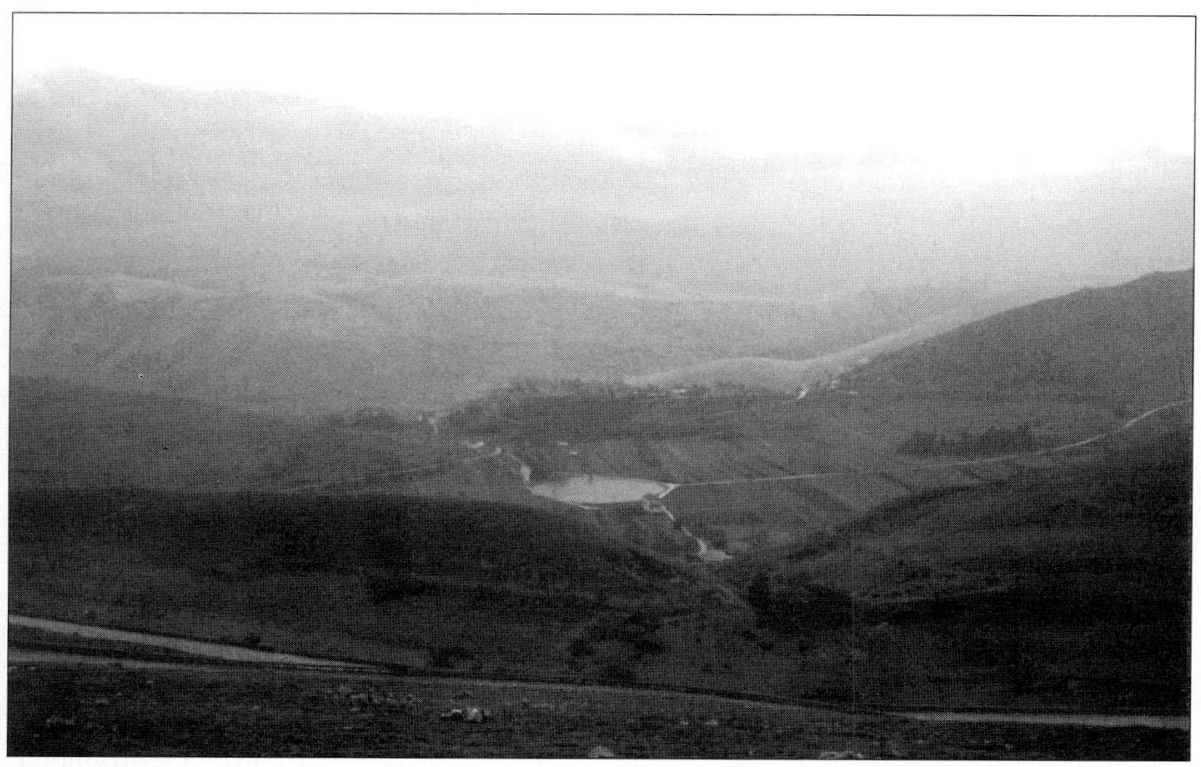

Fig. 1 - The small karst plain of S. Stefano di Sessanio (L'Aquila) 
c) in dolines of varying morphology, extension and altitude, the bottom is used for cultivation; in Abruzzo, and in the forms with greatest extension (e.g. the doline of Fossa Raganesca), the presence of stone clearing and dry walls inside the depression attest to a custom that is very deep-rooted and motivated by the need to make maximum use of all the available agricultural area; an example, perhaps emblematic, is the town of Gissi (Abruzzo), with a crown-like structure on evaporite gypsum outcrops that surround the broad internal doline intensely utilised for horticulture (Burri, 1985; 1994).

Other types of use of dolines are widespread throughout Puglia; also in this region the edges of the doline are protected by dry walls, which have the multiple function of defence from the dominant winds (at times cold, but also loaded with salinity) or protection of crops from excessive evaporation due to solar radiation. The tradition of using dolines for cultivation is further demonstrated by the works of artificial drainage of the basins found in the evaporite gypsum outcrops in the area of S. Ninfa (Burri, 1989) in Sicily, or in that of Verzino in Calabria, built to prevent swamping of the most depressed area. In the open fields, dominated by intensive cereal cultivation, the presence of sinkholes or dolines is considered a hindrance to the use of mechanical equipment; therefore they are filled or obliterated.

In the central Apennines, the predominant agricultural activities can be divided into wide altitude bands: the main crops in the higher band are chick peas, lentils, potatoes, grasspeas or any specialised crop (for instance, saffron in Piana di Navelli, in Abruzzo); at lower altitudes, the first almond and olive trees appear, and even lower, cereal crops predominate, traditionally associated with olive growing; however, today extensive tracts of olive groves and vineyards increasingly characterise the low altitudes of southern Italy. The cultivation of vegetables is limited in extent but concentrated, with the consequent necessity of irrigation and thus exploitation of the scarce water resources.

Other structures that characterise the karst landscapes and testify to a traditional transformation of the territory for agricultural crops are the nuclear settlements like the masserie of Puglia, the contrade of the Lessini Mountains, groups of houses built entirely in stone which because of the thickness of the walls seem to be constructed "caves". Also characteristic are certain temporary residences and refuges like the trulli of Puglia; other small refuges (used for tools or livestock) built with limestone blocks from stone clearing can be found in the Berici Hills (Pre-Alps in northern Italy), in the central Apennines and in Gargano (Puglia). Completing the list of stone structures are the stone-clearing piles and the dry walls for enclosures, protection and terracing.

Thus, the typical signs of the agricultural landscapes are:

- dry walls delimiting the agricultural plots,

- stone piles,

- terraces on hillsides supported by dry walls or artificial scarps,

- "terraccettes" or "pieds de vache", dense patterns of subparallel tracks produced along steep slopes by cattle grazing, 
- "trous monticules", nearly circular depressions with mounds of debris on one side, created where the soil and uppermost rock are torn up during the uprooting of tree stumps,

- small circular emplacements built on the slopes to host piles of timber for charcoal production,

- artificial ponds for grazing animals, created by sealing the floors of some dolines, digging depressions in clay and damming small dry valleys.

The water reservoirs, corresponding to the large karst springs at the boundary of karst morpho-units, have been exploited as far back as the Roman times in peninsular Italy, with the construction of large aqueducts like those of ancient Rome. In contrast, the waters of many large karst springs in north-eastern Italy have not been exploited by the towns of the Po Valley because the alluvial aquifers of the valley have been preferred. However, recently with the deterioration of the Po Valley water, the large karst reservoirs of some karst groups are becoming a strategic resource and their value has been reconsidered.

In the second half of the XX century, the techniques of utilisation of other resources, e.g. the marls, limestones, ornamental stones and marbles, have changed. Large quarries for cement production have been opened. In the Berici Hills, in a single quarry something like 2-3 thousand cubic metres of limestone are excavated daily. The Carrara Marble of the Apuane Alps and the Rosso Ammonitico of the Venetian Pre-Alps are exported throughout the world; the latter has been sold in some countries as "red carrara".

\section{Some typical aspects of human impact}

The karst areas not affected by the Pleistocene glaciation were normally mantled by nearly continuous regolite and soil covers, with a thickness of a few decimetres on the steep slopes and many metres in the bottom of large depressions.

The first phase of human impact started as far back as Protohistory and mostly involved land reclamation for grazing and agriculture. The soil use for grazing and agriculture, along with the use of fire, accelerated soil erosion leading to desertification of large surfaces.

The vulnerability of the soils is mainly controlled by the lithological and structural conditions of the soluble rocks and by the climatic regimes. The vulnerability is lower where the rock is densely fractured, as in some karst massifs of central Italy (for instance in the Massiccio del Gran Sasso) or on densely fractured marly limestones as in the Venetian Pre-Alps and in the central Apennines ("Biancone" FM and "Scaglia" FM, both chalk-type limestones). In these types of limestones, desertification is less conspicuous because a thin soil develops even in a short period.

The intensely karstified massive limestones have shown greater vulnerability to human impact. The landscape of the upper part of the Sette Comuni plateau, mostly in Jurassic massive limestones, is strongly desertified despite the abundant precipitation (more than $2000 \mathrm{~mm}$ yearly), in contrast to the upper part of the Lessini Mountains, mostly in Cretaceous chalk-type limestones. 
The table highlights the most typical resources of the karst environments and their spatial framework before and after the desertification induced by the human impact.

\begin{tabular}{|c|c|c|c|}
\hline \multicolumn{2}{|c|}{$\begin{array}{l}\text { FIRST } \\
\text { SETTLEMENT }\end{array}$} & \multicolumn{2}{|c|}{$\begin{array}{l}\text { AFTER DESERTIFICATION FROM } \\
\text { HUMAN IMPACT }\end{array}$} \\
\hline $\begin{array}{l}\text { Widespread } \\
\text { resources }\end{array}$ & Scattered resources & $\begin{array}{l}\text { Widespread } \\
\text { resources }\end{array}$ & Scattered resources \\
\hline $\begin{array}{l}\text { Soil and vegetation } \\
\text { for wood, grazing and } \\
\text { agriculture } \\
\text { - Stone for building } \\
\text { - Stone for the } \\
\text { production of lime } \\
\text { - Wood }\end{array}$ & $\begin{array}{l}\text { - Natural shelters } \\
\text { - Water } \\
\text { - Clay for } \\
\text { waterproofing of } \\
\text { basins and tanks } \\
\text { - Chert for the } \\
\text { making of tools } \\
\text { - Special stone } \\
\text { types for artefacts } \\
\text { (massive limestones, } \\
\text { marbles, breccias, } \\
\text { etc.) }\end{array}$ & $\begin{array}{l}\text { - Stone for building } \\
\text { - Stone for the } \\
\text { production of lime } \\
\text { and cement }\end{array}$ & $\begin{array}{l}\text { - Natural shelters } \\
\text { - } \quad \text { Water } \\
\text { - } \quad \text { Soil and vegetation } \\
\text { for wood, grazing and } \\
\text { agriculture } \\
\text {. } \quad \text { Clay for } \\
\text { waterproofing of } \\
\text { basins and tanks } \\
\text { - Chert for the } \\
\text { making of tools } \\
\text {. Special stone } \\
\text { types for artefacts }\end{array}$ \\
\hline
\end{tabular}

Table 1 - Typical resources in karst areas, before and after the desertification induced by human impact.

In some areas of the Venetian Pre-Alps, rocky spikes sculptured by typical subsoil rundkarren are now as much as $1 \mathrm{~m}$ above the general level of the remaining soil. More advanced desertification can be recognised in some areas with a typically Mediterranean precipitation regime, frequent fires and excessive animal pressure on the pastures. In some karst environments of the Mediterranean mountains, e.g. the Supramonte Mountains of Sardinia, Madonie and some gypsum ridges in Sicily, the stony deserts are truly impressive.

The second phase of human impact, widely overlapping with the previous one, involved the construction of the human cultural landscape, through the building of many different structures for better use of the land, the division of plots, the reduction of soil erosion, etc. Some of these structures are among the signs of the human landscape described previously.

The third phase, the recent one, is marked by the marginalization and desertion of most karst areas, in which the recovery of soil and vegetation is now occurring.

The karst areas, like most marginal mountain and hill areas, have suffered an intense rural exodus and abandonment of agriculture since the mid-1800s, but especially in the last 50 years: among the main causes of this are the progressive decrease of competitiveness of small family farms and the search for more profitable jobs and better living conditions. Vast agricultural zones in northern, central and southern Italy have been strongly affected by emigration toward extra-European, and later European, countries.

In addition to the general factors characterising this phenomenon, the shortage of 
water, the thinness of the soil and the small size of cultivated plots, which had already made the situation of farmers in karst areas precarious, have contributed strongly to the increased intensity of the agricultural exodus.

As a consequence of this abandonment, bush is expanding rapidly in most karst areas, at first exploiting the soil pockets inside the karren traps. After World War I, the rocky desert of the Classical Karst of Trieste evolved first into brushwood and then, in the last few decades, into a forest environment. In some mountain areas, e.g. the Supramonte di Oliena in Sardinia, a typical Mediterranean wood is developing, and in certain high mountain karsts a mugo pine bush is masking the rocky landforms. The revived arboreal vegetation is an expression of the high regenerative capacity of karst environments, even though the development of soil and vegetation covers similar to those destroyed by human impact will certainly require a very long time.

In the last decade, there has been a reversal of the trend locally and a partial agricultural recolonisation of previously abandoned areas. There are two basic reasons for this: the availability of low-cost, even clandestine, manpower from poorer European and extra-European countries, and market demands for certain agricultural products (artisan products or those guaranteed by a specific mark of genuineness and origin).

Finally, other forms of degradation or pollution due to agricultural practices in karst areas can be summarised as:

a) degradation of slopes and valley bottoms, obliteration of sinkholes, filling of dolines;

b) pollution of karst reservoirs by pesticide and fertilizer runoff;

c) heavy use of aquifers for irrigation, with loss of the natural refilling capacity. Near the coast, and very frequently in the zone of the Murge in Puglia, lowering of the level of karst aquifers causes occasionally irreversible pollution due to infiltration of salt water.

\section{An example of the recent trends of the man-karst environment relationship: The Monti Lessini and Monte Grappa (Venetian Pre-Alps)}

Because of the great diversity of the Italian karst morpho-units, it is not possible to provide an exhaustive framework here. Thus only some typical cases are briefly analysed.

Some typical aspects of resource exploitation and human impact in the Venetian Pre-Alps were illustrated by U. Sauro $(1987,1993)$. The Venetian Pre-Alps, the southern sector of the eastern Italian Alps, constitute a belt of well-defined karst morpho-units, marking the transition between the Alps and the Venetian Plain. The upper Venetian Plain is one of the most urbanised areas in Italy, characterised by a wide variety of well-diversified industrial activities.

The control of the towns on the resource utilisation of the pre-alpine karst areas has been evident since the Middle Ages. According to the distances of the karst areas from the towns and the importance of the mountain communities, different types of strategies have been developed, fundamentally based on the use of the same resources: stones, lime, forests, agriculture, pastures, the production of fuel, timber, char- 
coal, cereals, vegetables, fruit, dairy products, meat, hides and wool. Phases of strong impact in some areas, e.g. the excessive pressure from sheep on the pastures of the Sette Comuni Plateau in the XVIII century, have been induced by arbitration agreements between the business of the local communities and that of the urban wholesalers and the State.

Following urbanisation and industrialisation of the upper plain, some mountain areas of the Venetian Pre-Alps have been partially integrated in the new territorial dynamic, while others have been marginalized.

The Lessini Mountains and Monte Grappa represent two different models of evolution.

The proximity of the Lessini Mountains to Verona and Vicenza and to their industrial appendices, situated in the wide valley bottoms, has favoured the progressive integration of the mountain area in the new urban and industrial dynamic. This dynamic has resulted in the growth of different economic activities and in land occupation by productive structures.

In the post-World War II period, a first phase saw the expansion of quarrying, marble cutting, tannery and clothes industries in the wide southern valleys and of tourist infrastructures in some mountain villages. From the $1960 \mathrm{~s}$ to the $1980 \mathrm{~s}$, a second phase was characterised by the development of complexes of vacation cabins, condominiums, ski resorts and access roads, and by the rise in the hill, low and middle mountain belt of a large number of specialised sheds for hog farming, cattle breeding, poultry and turkey farming. This type of growth was favoured by the expansion of some animal feed factories in the valleys.

During this phase, while the traditional agriculture of the mountain ridges (aimed at self-sufficiency of the local communities) faded away, cattle breeding and the use of high pastures during summer increased. In the 1980s, the number of animals per surface unit in the high pastures was 2.5 times the average of pastures in the other pre-alpine groups.

This type of development led to the introduction of a huge amount of living biomass that exceeded the productivity of the local environment. The deficiency has been covered by the introduction of large quantities of animal feed. The raw sewage production of nitrogenous compounds greatly increased, roughly corresponding to that of cities of 200,000-400,000 persons (Sauro, 1993), with subsequent environmental problems due to the liquid wastes and pollution of the karst springs.

In the $1990 \mathrm{~s}$, there was a retrenchment of some breeding activities, especially hog farming, and the pressure on some areas, e.g. high pastures, also decreased. Today the trend is towards a standardisation of the breeding methods, with a gradually decreased use of local resources. Therefore, the mountain area is evolving into a simple container of agro-industrial structures, more and more independent of the local environmental framework. One benefit is probably that of greater salubrity than in the agro-industrial areas of the plain. In fact, a recent viral epidemic in poultry farms of the plain did not spread to those of the mountain area.

The increased human impact in areas with high tourism pressure and rich in natu- 
ral monuments, biotopes, etc., has prompted much debate on conservation problems, leading to the institution of the natural park of Monti Lessini. Today the development of the park is clashing with the many problems caused by the different types of human pressure.

The territorial dynamic of Monte Grappa is relatively simpler, also because of its marginal location with respect to large urbanised areas. A strong impact occurred during the World War I, when the area becames a theatre of battles (fig. 2). The development of cabin complexes took place on a few ridges between the 1960 s and $1980 \mathrm{~s}$, but it stopped in a short time because of the lack of permanent villages.

A progressive decrease in the use of high pastures has also occurred, with overgrowth of the forest. Frequentation of the high mountain is mostly linked to weekend tourism.

Therefore, even though the intensity of human pressure on the two karst morphounits is greatly different, a progressive distortion of the traditional man-environment relationship has taken place in both, illustrated by the consequent obliteration of the human signs in the landscape that were the expression of this relationship. The landscapes are acquiring new identities, partially linked to the urban-industrial network inside the complex economy integrated at a regional, national and worldwide scale.

In this perspective, besides the land, the only typical environmental resources that are assuming strategic importance in time are the stone and water reservoirs: however, the former is a non-renewable resource, while the latter is undergoing continuous

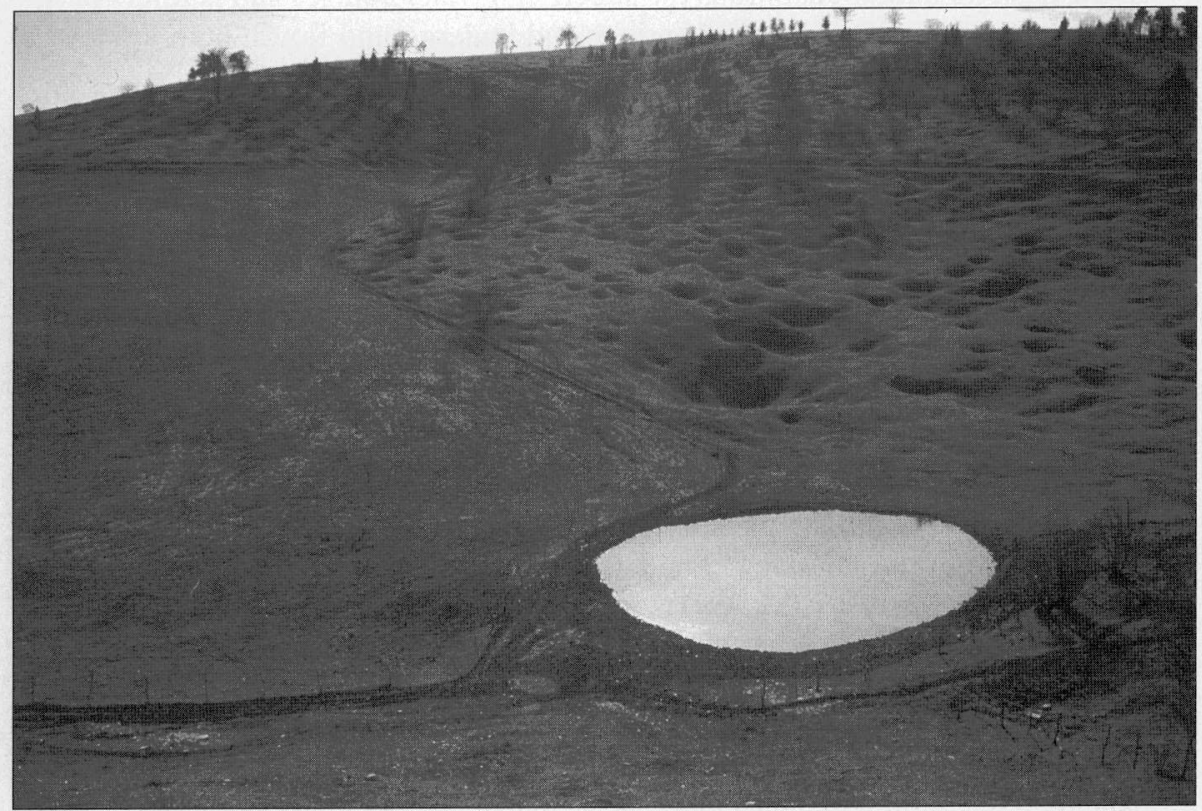

Fig. 2 - Soil erosion by pasture and bomb holes in Monte Grappa. 
deterioration. Nevertheless, the characteristics of natural and/or seminatural space remain and the areas are rich in environmental niches, potential laboratories for citydwellers in the discovery of both natural habitats and problems of human impact.

The challenges for the next few decades will be to mitigate some types of human impact and to rediscover, within the parks and natural reserves, the traditional styles of resource use, linking these with the promotion of agricultural tourism.

\section{Fucino: the lake that became land}

The Fucino depression is a typical Apennine intermontane basin and, from the morphostructural point of view, a tectonic fossa (graben). Its hydrographic basin extends for around $900 \mathrm{~km}^{2}$ and is delimited by carbonate peaks of the LazioAbruzzo Apennines. It is a large closed basin characterised by an extensive alluvial plain of more than $200 \mathrm{~km}^{2}$ (see picture in front cover).

This depression is not properly a karst basin, but rather a complex tectonic-erosive form; however, it is closed topographically on account of a karst-type drainage. Thus it can be considered a "tecto-karst" depression. The carbonate slopes and massifs surrounding it are karst. The filling by detrital alluvial and lacustrine sediments has a thickness of a few hundred metres, even exceeding $1000 \mathrm{~m}$ locally. The tectonic processes are still active, as shown by strong earthquakes like that of Avezzano in 1915, one of the most serious natural calamities to strike central Italy in the XX century.

In the past, in natural conditions the superficial water courses and aquifers of the carbonate massifs fed, by means of springs and underground flows, both a phreatic aquifer housed in the alluvial complex of the basin and a vast lake.

The water level of this lake was subject to large oscillations, caused by climatic variations and the discontinuous operation of the karst sinkhole called "la Pedogna", situated NW of the town of Luco dei Marsi, and of others not well identified. Many factors affected the operation of the sinkholes, including the inflow of sediment by means of runoff waters and streams.

In the Palaeolithic, man was an idle spectator of the large oscillations of the lake level. In the Neolithic and in Protohistory, following the development of agriculture, the plain became a "cultivated oasis", surrounded by slopes used for grazing. However, forest clearing and grazing accelerated the soil erosion, favouring the temporary obstruction of the sinkholes and consequent expansion of the lake and reduction of cultivable areas in the plain.

The problem of oscillations of the lake surface was tackled in the I century AD, when the Romans constructed a $5640 \mathrm{~m}$ long underground tunnel. It was able to drain the excess water and expose around $80 \mathrm{~km}^{2}$ of land that was particularly fertile on account of its muddy texture.

The remaining lake was used for fishing and acted as an expansion area for possible flooding. There are no historical accounts of the types of crops, although it is probable that in addition to wheat and grapes, vegetables were grown for the markets of Rome. 
After the fall of the Roman Empire, the progressive lack of maintenance of the tunnel, together with other natural causes (collapses inside the tunnel perhaps related to strong earthquakes, wet climatic phases), favoured expansion of the lake, perhaps starting from the VI/VII century AD.

In the mid-1800s, a new artificial underground collector was built. This led to the definitive disappearance of the lake and the reduction of the present water reserve in the basin by a quantity estimated at more than $1 \times 10^{9} \mathrm{~m}^{3}$ of water. Thus the natural ecosystem (hydrogeological and biological) was upset and with it the social and economic order of the population.

The State assigned ownership of the reclaimed territory (more than $140 \mathrm{~km}^{2}$ ) to the financier of the hydraulic work. The owner then built over $200 \mathrm{~km}$ of roads, 100 $\mathrm{km}$ of canals and $600 \mathrm{~km}$ of drainage ditches. The immense property was then divided into direct-management farms (2,800 ha), métayages (900 ha) and tenancies (9,300 ha). The system of tenancies was established to allow the recovery of capital invested in the reclamation. However, this system led to an extreme fragmentation of property, since each tenant then divided his land into smaller portions to be leased. This had an effect on the pro capite income, derived essentially from traditional crops (wheat, corn, beet, potatoes and beans, with triennial rotation) and limited water demand. In fact, the waters in the basin were sufficient for the agricultural activities and the dense net of artificial canals created by the reclamation permitted a good territorial distribution of the water resources. In 1951, the immense property was expropriated and divided into plots of $1 / 1.5$ ha, which were assigned to the inhabitants of the plain.

Since the 1960s, human pressure on the Fucino area has gradually increased because of the development of urban centres but especially the modifications of agricultural organisation and cultivation systems. In particular, the water demand has increased, also in relation to new horticultural crops which are extremely waterneedy (fig. 3). Indeed, the current exploitation involves two/three crop cycles. This causes strong pressure on the water resources, which is aggravated by two factors:

a) a system of sprinkler irrigation, not rationalised according to the needs of the crops and able to disperse a larger quantity of water than theoretically needed;

b) the lack of a responsible authority, able to discipline the withdrawal and use of the water resources.

To understand the problems of human impact on this geo-system, it should be considered that the Fucino plain constitutes a hydrogeological unit that is well defined but dependent on the adjoining units: it is a sedimentary complex derived from alternations of detrital-alluvial levels (gravels, sands, muds and clays), whose permeability is extremely variable according to the grain size.

From the point of view of natural dynamics, the inflow is determined by precipitation and by superficial flows. The latter consist of streams and karst springs feeding the hydrographic network, which only minimally penetrate in depth to reach the alluvial water layer because of the limited permeability of the sediments on the plain's surface. The water layer in the alluvia of the plain is instead fed mainly by under- 


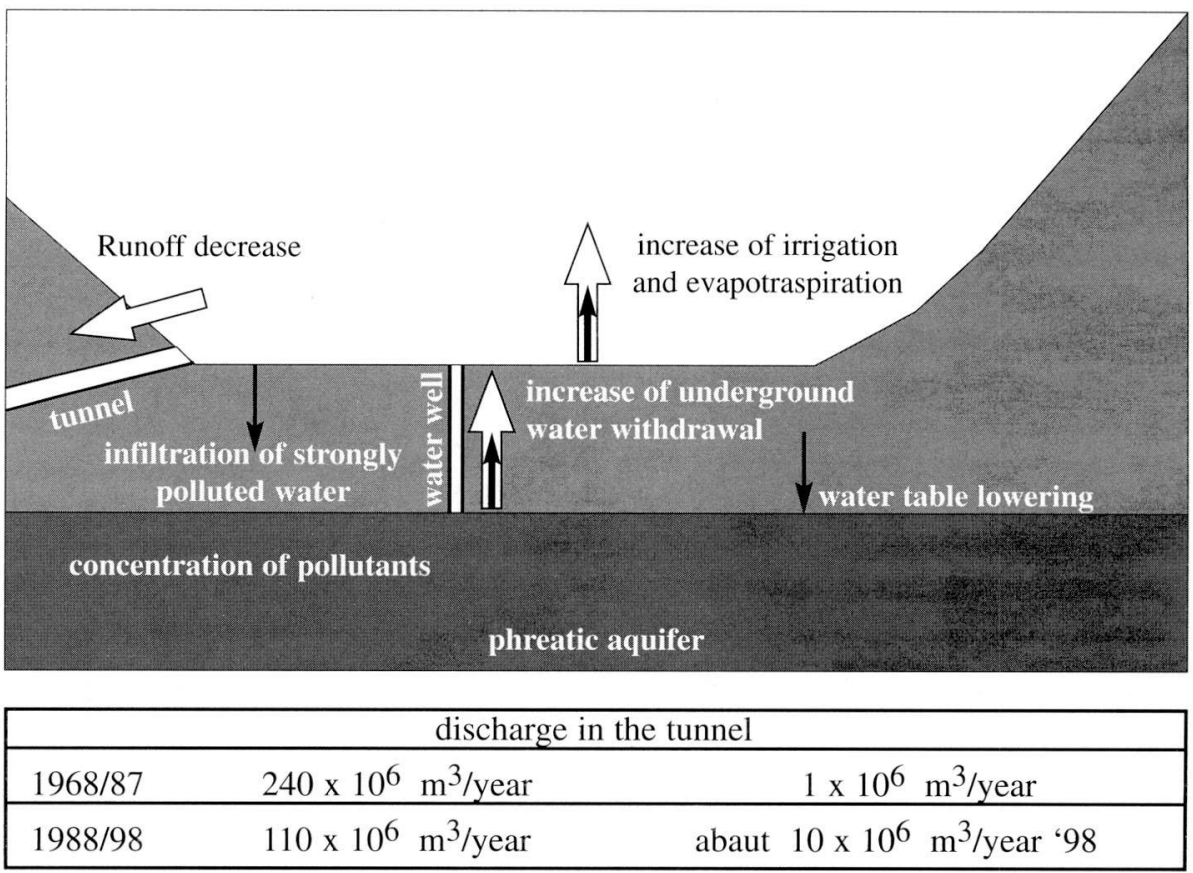

Fig. 3 - Schema Fucino

ground flows from the surrounding karst aquifers.

The losses are due to evapo-transpiration, estimated at $450 \mathrm{~mm} / \mathrm{year}$. The water excess in the basin, concentrated exclusively from October to April, can be estimated at only 240 mm/year (Burri, 1991; Burri e Petitta, 1998; Burri e Petitta, 1999).

\section{The Murge}

The Murge is a low karst plateau in Puglia (southern Italy), marked in its central part by a honeycomb system of very large, closed, relatively shallow depressions. Their surface areas can reach a few square kilometres (fig. 4).

Wide dry valleys with flat bottoms, called Lame, are nested on the slopes of the depressions and on the external scarps. A few large deep dolines, called Pulo, form geomorphological peculiarities inside the plateau.

This karst may be considered a low relief energy "cockpit karst", according to its morphological style. Some fluvio-karstic features were superimposed following different episodes of volcanic ash falls that mantled the relief and induced the development of a hydrographic network (Sauro, 1991).

Volcanic ashes are the parent material of the plateau soils, very fertile for cereal cultivation. The human impact started with forest clearing and continued mainly with sheep grazing. Soil erosion on the slopes led to desertification of the slopes and to 


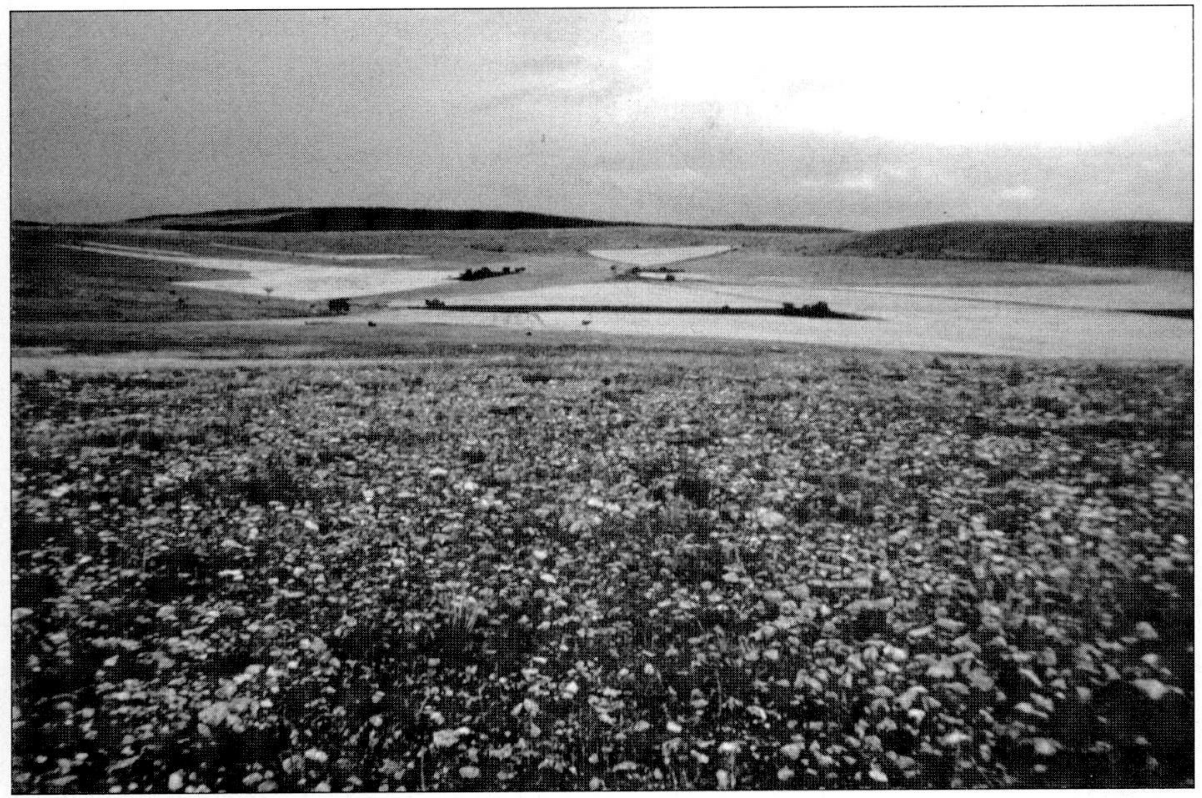

Fig. 4 - Large karst depression in Murge plateau.

accumulation of soil sediments in the valleys and depression bottoms. In this way, agriculture became oasised in nearly circular plots inside the large depressions and narrow strips in the flat valley bottoms. Outside the cultivated areas, there is barren pasture, used today for sheep grazing. A complex system of dry walls encloses the cultivated plots.

Because of wheat growing, bread is a typical product of the small towns of the plateau.

\section{Two examples of the analysis of agri-karst landscape evolution}

"Le paysage est très précisément et tout simplement ce qui se voit" (Brunet, 1974): this statement, among several that can be attributed to the idea of landscape, makes us understand landscape as an appreciable datum, as a display, as an evident sign of the interplay of natural and human processes, phenomena and factors interacting within the territory. The essential characteristics of an agro-karst landscape derive from peculiar natural dynamics (karst), peculiar human dynamics (agriculture) and peculiar relationships between them.

However "Ce qui se voit est un signe pour le chercheur" (Brunet, 1974): although everybody can see it, the appreciable datum can be an interesting starting point to investigate the dynamics of natural and human factors and processes. Also in karst areas, a large amount of information concerning man-environment interactions can be obtained by the analysis of landscape signs. 
Landscape analysis can be performed from very different perspectives: for example, it can be directed towards a simple description of landscape elements in a didactic perspective, or towards the evolution and changes that occurred in different time scales for geomorphological or historical reviews, or towards environmental planning.

Two examples of landscape analysis are presented here: using different methods (quantitative vs. qualitative), they indicate the most important events of landscape evolution in the last few decades in two Italian karst areas.

\subsection{A quantitative method of landscape analysis: the case-study of the Berici Hills (Venetian Pre-Alps)}

The main aspects of agricultural impact in the southern plateau of the Berici Hills have been studied through an analysis of land use evolution with a geographic information system (GIS) application.

The area is a rather low karst plateau (150-300 m a.s.1.) with Eocene marly limestone outcrops; there are many dolines and uvalas intercalated with knolls on its surface. Agricultural activities occupy a large part of the plateau, but their nature has changed in the last 50 years due to the profound changes in the social and economic context.

This analysis was carried out according to quantitative criteria, using data drawn from 1:5000 scale regional technical cartography and aerial photos, verified by field investigations. Three time situations (1956 - 1982 - 1996) were compared, relating to three available air photo strips. With the IDRISI GIS, it was possible to create a land use thematic map for each examined situation. This material, together with a relief map, was the basis for further surveys and processing (by means of the GIS). Percentage areas of each category of soil exploitation were calculated in the three phases, allowing a quantitative comparison; moreover it was possible to relate each feature to the geomorphological framework.

For the thematic maps, different kinds of soil exploitation were collected in some categories: wood (mainly a coppice still used or with recently ended cutting, present in fairly narrow plots of lands); scrub (typical thermophilic brushwood of the zones with highest soil erosion, or thin forest connected to extents of wood or to its extreme exploitation); meadow - cultivation (mostly mown meadows and maize and forage fields); vineyard and buildings.

\section{a. General land use evolution}

The graph (fig. 5) illustrates the percentage subdivision of land use categories in the area in the three time situations and allows us to observe their evolution. The percentage of productive land (meadow-cultivation and vineyard) is nearly constant in comparison with less or non-productive land (wood and scrub); however, in the chronological sequence obtained by comparing the 1956, 1982 and 1996 situations, some basic changes in soil exploitation can be noted.

The first one is the change of scrub into wood, due mostly to the increase of the 


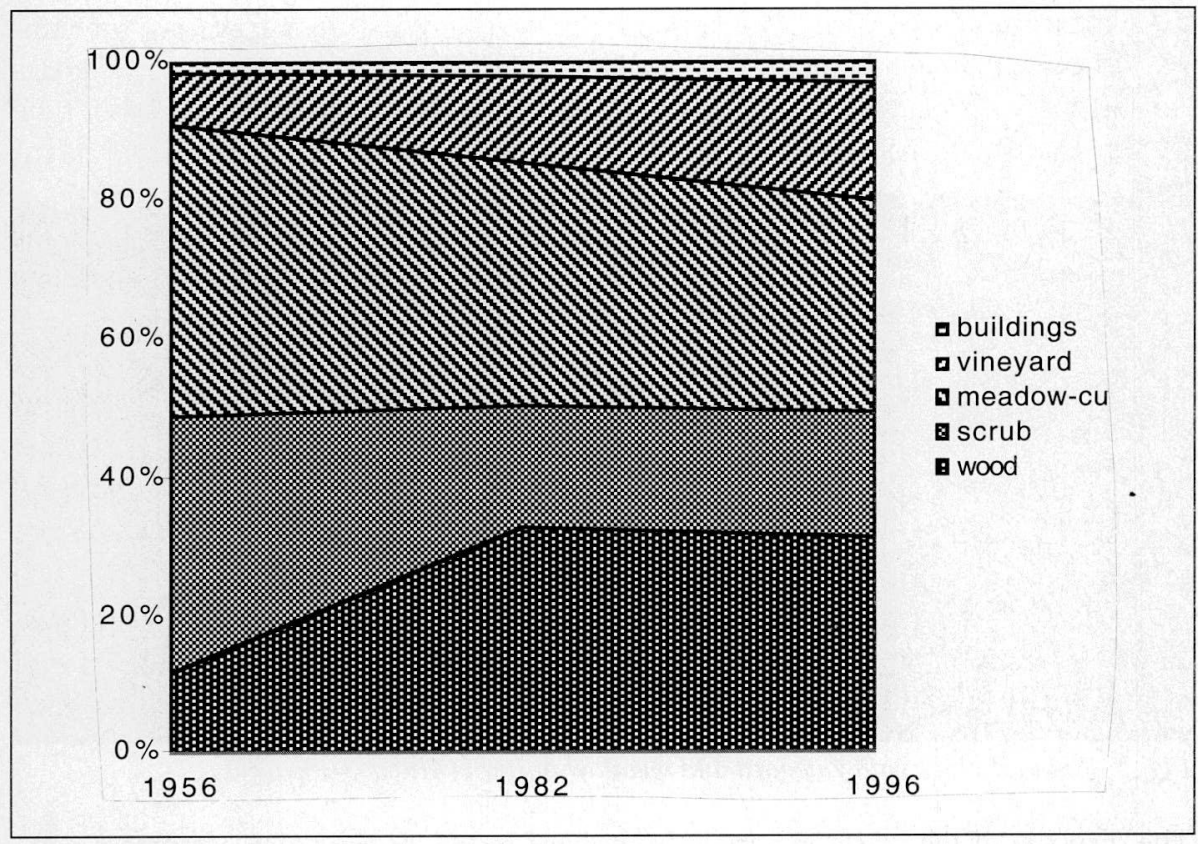

Fig. 5 - Land use evolution in the sample area in Berici Hills.

intervals of coppice cutting.

The second profound change in the landscape in recent years (mostly from 1982 to 1996) is the decrease of meadow-cultivation categories and the progressive increase of vineyards. This is a very considerable landscape variation, marking the transition from a type of agriculture requiring a lot of labour and little machinery (mainly for self-consumption) to a kind of company agriculture that seeks the most fruitful and suitable cultivation (in a sunny unfoggy place, characterised by thin, water-poor soil) and increasingly rejects economically unfavourable, albeit traditional, cultivation (fig. 6).

Moreover, the changing land use and the consequent impact on the landscape are increasingly profound because of different vine cultivation techniques that considerably change the features of the area: narrow rows of vines linked to live supports (fruit trees, maples, mulberry trees, etc.) alternated with meadows (1956 situation) were replaced by real vineyards with wooden stakes as supports (1982) and then by wider and wider plots of land with concrete piles, mostly in the softer morphology zones and wider dolines (1996).

In the 1982 and 1996 situations, poultry or rabbit breeding farms are also considered in the "buildings" category: they can be clearly seen in the landscape, with their huge sheds extending onto the knoll from doline to doline, and they make the landscape seem less "agricultural"; they look like a sign of "industrialisation" on these hills which instead maintain their traditional traits of agricultural landscape. 


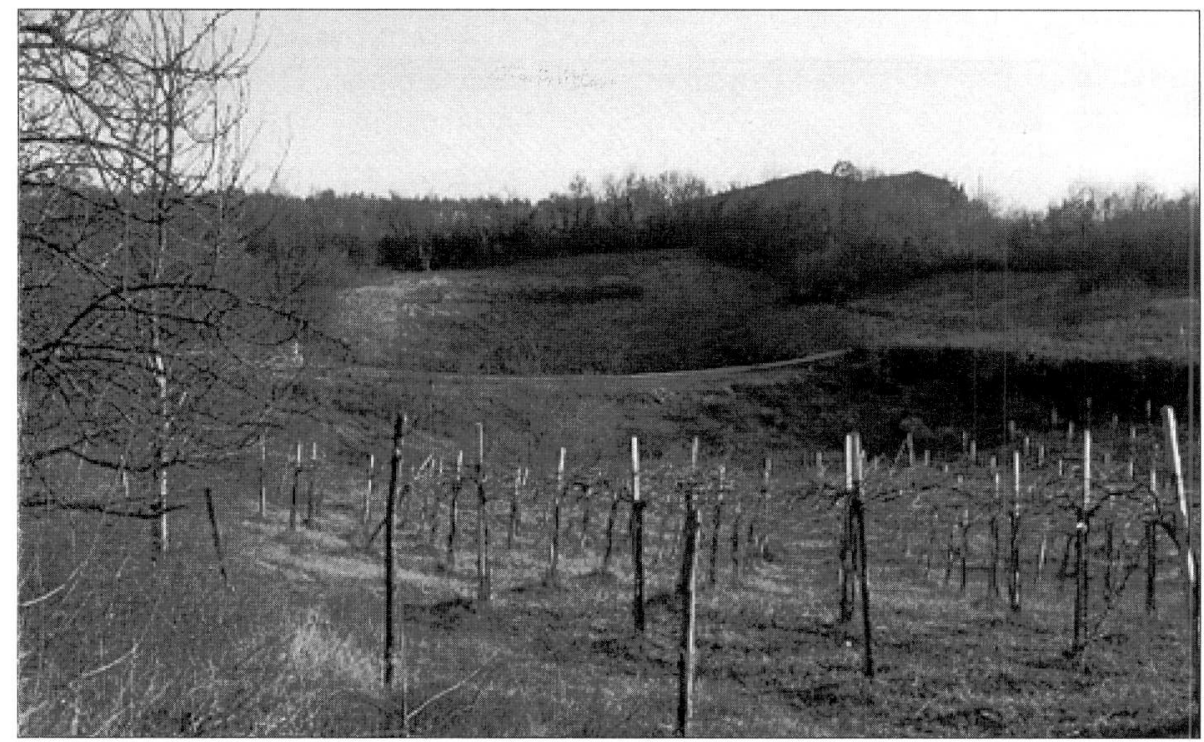

Fig. 6 - Small dolines with vinegard and meadow in Berici Hills.

The disposal of the waste materials from these installations is also a problem concerning the impact of such activities on the landscape.

b. Distribution of land use categories according to the geomorphological framework

The landscape of this part of the Berici Hills is characterised by the fragmentation and continuous alternation of small and medium-sized landforms (dolines with their sometimes terraced slopes and rather flat bottom, and small ridges and knolls among contiguous depressions). The size and distribution of plots of land and different soil exploitation typologies are related to these landforms. The result is the typical landscape structure of this and other doline landscapes, which can be defined as "leopard spotted". Some quantitative analyses of the relation between relief shapes and land use have been carried out; they show the different uses linked to these factors and illustrate how this relation has changed in the last 50 years.

With the GIS analysis, it was possible to distinguish the external areas of depressions from the inner ones and, within this category, between the inclined slopes and the doline's central subflat area (the bottom). Some observations can thus be made on the basis of table 2 .

The general trend of landscape evolution is generally observed both inside and outside the dolines (unchanging percentage of cultivated areas, progressive increase of vine cultivation and decrease of meadows and cultivations, change of scrub into wood); however, a distribution of land use categories in exact relation to morphology is noticed.

The bottom of the depressions is almost $80 \%$ cultivated, reflecting its characteri- 


\begin{tabular}{|l|l|l|l|}
\hline 1956 & bottom & slopes & $\begin{array}{l}\text { external } \\
\text { areas }\end{array}$ \\
\hline wood & $6,44 \%$ & $18,11 \%$ & $8,24 \%$ \\
\hline scrub & $15,11 \%$ & $36,79 \%$ & $43,72 \%$ \\
\hline $\begin{array}{l}\text { meadow- } \\
\text { cultivation }\end{array}$ & $68,78 \%$ & $39,50 \%$ & $37,19 \%$ \\
\hline vineyard & $9,68 \%$ & $5,24 \%$ & $9,01 \%$ \\
\hline buildings & $0,00 \%$ & $0,36 \%$ & $1,82 \%$ \\
\hline \hline $\mathbf{1 9 8 2}$ & & & \\
\hline wood & $15,75 \%$ & $40,28 \%$ & $32,49 \%$ \\
\hline scrub & $6,10 \%$ & $17,27 \%$ & $20,59 \%$ \\
\hline $\begin{array}{l}\text { meadow- } \\
\text { cultivation }\end{array}$ & $58,74 \%$ & $32,92 \%$ & $30,35 \%$ \\
\hline vineyard & $19,36 \%$ & $8,64 \%$ & $13,09 \%$ \\
\hline buildings & $0,05 \%$ & $0,90 \%$ & $3,46 \%$ \\
\hline \hline 1996 & & & \\
\hline wood & $14,55 \%$ & $38,82 \%$ & $30,25 \%$ \\
\hline scrub & $8,08 \%$ & $20,38 \%$ & $20,30 \%$ \\
\hline $\begin{array}{l}\text { meadow- } \\
\text { cultivation }\end{array}$ & $48,28 \%$ & $27,15 \%$ & $27,77 \%$ \\
\hline vineyard & $28,79 \%$ & $12,65 \%$ & $16,38 \%$ \\
\hline buildings & $0,29 \%$ & $1,00 \%$ & $5,27 \%$ \\
\hline
\end{tabular}

stics of soil thickness and high humidity. The percentage of vine cultivation, which was very low with respect to the other kinds of cultivation in 1956, increases with time more than in the other places, while there are virtually no buildings.

In the time period considered, the doline slopes are the only areas where a slight decrease of the meadow-cultivation and vineyard categories is observed; their percentages, however, are less than the general average (from $44,74 \%$ in 1956 to $41,56 \%$ in 1982 to $39,8 \%$ in 1996). In contrast, the slopes are the areas with the highest percentage of wood, even when wood areas are rather reduced (1956). This condition is due to their steepness, which hinders cultivation, and sometimes to unfavourable exposures, which

Table 2 - Evolution of land use in the sample area of Berici Hills, according to geomorphological framework. make the lower parts of the slopes rather cool and extremely moist.

Two observations can be made about the external areas of the dolines. First, the percentage of uncultivated areas seems to be slightly higher, with scrub being most frequent: indeed, the external areas of dolines have favourable conditions for the establishment of thermophilic and xerophilic scrub communities (they are the driest and sunniest areas). Second, the category "buildings" shows a clear preference for the areas between one doline and the next, and this preference remains as time goes by: in fact, for this kind of use, the exposure and ease of access are more important than soil thickness.

\subsection{A qualitative method of landscape analysis: the case-study of Gargano (Puglia, southern Italy)}

GIS land use analysis is very problematic where large-scale maps are not available. Therefore, different criteria were applied to the study of the landscape of the inner part of the Gargano promontory.

This region is a large inclined doline plateau, from 900 to $400 \mathrm{~m}$ a.s.1., crossed by 
some low ridges. In places, there is very intense soil erosion, while elsewhere there are quite deep colluvial covers of soils previously evolved on volcanic ash.

Since the landscape is "what we can see", in this case the landscape analysis is based only on the identification of the principal elements, recognised on maps, aerial photos or in field work. The significance of each element can then be defined, in a kind of reading process. In the end, many elements together allow us to recognise the most important features of the present and past situations: they allow us to understand the dynamics in which natural and socio-economic factors are and were involved.

The changes from the traditional agricultural landscape, with a large number of isolated farms and almost all the land used for cultivation and grazing (as can be recognised in the aerial photos of the 1950 s), to the present situation, with only a few active farms, extensive grazing and a rural exodus from most of the region, are well identified with this method of landscape analysis. Although natural and human features are closely linked, they have been differentiated in the following description so as to better analyse each element.

\section{Natural elements}

There are limestone outcrops and karst landforms on the entire Gargano plateau, especially dolines, uvalas and dry valleys. One very large doline (Dolina Pozzatina) is $600 \mathrm{~m}$ long, $400 \mathrm{~m}$ wide and more than $120 \mathrm{~m}$ deep, while other forms are in general small or medium-sized.

The natural vegetation is oak wood (Quercus cerris) and its distribution depends on the type of human exploitation: due to the present abandonment of agricultural practices, it is growing in increasingly larger spaces. A general condition in the first phases of the abandonment of cultivation and intensive grazing is the explosive growth of two weed shrubs, fern (Pteridium aquilinum) and asphodel (Asphodelus $s p$.). This makes it difficult for other natural species to grow: the re-establishment of vegetation in equilibrium with ecological conditions and with a high level of biodiversity requires a rather long time, especially in areas where extensive grazing still exists.

The analysis of aerial photos indicates an area in which wood was present until the 1970s and then was quickly cut; many circular charcoal pits (5-8 $\mathrm{m}$ in diameter) are distributed in this area, especially on the bottom of dolines, together with stone shelters for charcoal burners. It was an area of coal production until recent times, and probably in the last phases of land abandonment, wood was cut and utilised as the only remaining resource.

Many fruit trees and large chestnut trees are distributed in this area, especially near old buildings; they represented an important resource for farmers, as well as a shady spot in the hot summer.

\section{Human elements}

Many of the human elements in the Gargano plateau landscape refer not to pre- 
sent settlements or activities but merely to human presence in the past. The current activities can be found only along the two or three asphalt roads.

An important sign of past human presence is the large number of farms and isolated small houses that are now only ruins, but in which some aspects of the peasant and shepherd way of life can be recognised. In particular, various systems to collect and preserve rain water are very interesting: wells, large stone tanks, gutter systems and waterproof paving.

Many ruined dry walls divide plots of lands that had different uses or follow old tracks. Many of them support the terraces on doline slopes; the practice of terracing was well developed, with some examples of six or even seven steps on a single steep slope (fig. 7).

In the areas where human activities are still present, different signs can be found in the landscape: cultivated plots of lands with corn, fodder plants, sunflowers and legumes are distributed according to the relief characteristics; zones with deep soil are preferred, and doline bottoms are also cultivated. In places, the slopes have been arranged with the help of bulldozers to enlarge plots and to eliminate stones; large stone blocks are often thrown into the dolines, in correspondence to sinkholes.

Some old farms and houses have been restored and new houses have been built; in some cases there are permanent settlements, especially large farms with grazing and fodder plantations; in many other cases, people (often old people) live in the nearby villages and come to their small holdings during the weekend for part-time farming.

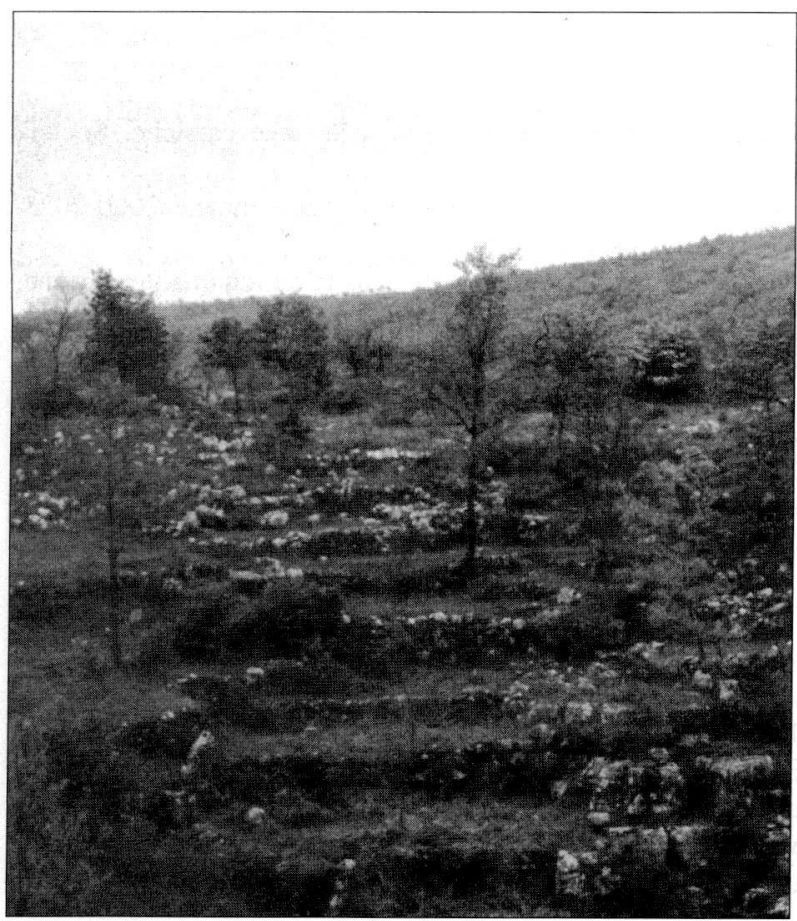

Fig. 7 - A large doline on the Gargano plateau: the 7 terraces on its slopes are completely abandoned. 
In conclusion, the analysis of landscape signs indicates that, in the Gargano karst plateau, agricultural practices were well developed with traditional characteristics until a few decades ago. A general rural exodus then completely changed the area, which now appears abandoned. Even though this area is part of the National Park of Gargano, no attention seems to be paid to making good use of the resources for sustainable development: obvious signs of this absolute negligence are the wrecked cars thrown down into almost every doline!

\section{Conclusion}

In Italy, there is a wide variety of karst morpho-units with different geological and geomorphological evolution, land reclamation and human impact history. The mosaic of human landscapes is complex and varies in relation to the different types of land use, the pattern of agricultural plots, the utilisation of peculiar resources (e.g. the different types of soluble rocks), the structure of settlements, and the variety and "stratigraphy" of the signs left by man.

Most of the landscapes present oasised agriculture according to the thickness of the soil cover, which depends on the morphodynamic processes and types of landforms.

In recent times, while a few karst areas have been integrated in the new economy, most karst morpho-units have been gradually deserted and are now undergoing the expansion of wood.

\section{REFERENCES}

AA.VV., 1989. Problemi di inquinamento e salvaguardia delle aree carsiche. Società Speleologica Italiana e Club Alpino Italiano.

AA.VV., 1988. Avenir du bassin méditerranéen. Environment-Development 2000-2025. UNEP (OCA) MED IG., 2/inf. 5, PNUE, Athenes.

AA.VV., 1989. Implications des modifications climatiques dans la region méditerranéene. UNEP (OCA) MED IG., 1/inf. 9, PNUE, Athenes.

AA.VV., 1987. Promotion of soil protection as an essential component of environmental protection in Mediterranean coastal zones. MAP Technical Reports Series n. 16, UNEP, Split.

AA.VV., 1988. I Colli Berici: natura e civiltà. Editoriale Programma, Padova.

ANGELICCHIO N., BISCOTTI N. and FIORENTINO F., 1993. Paesaggio nel Gargano. Schena Editore, Fasano di Brindisi.

BELLONI S., MARTINIS B and OROMBELLI G., 1972. Karst of Italy. In HERAK M. and STRINGFIELD V. T. (eds), Karst: important karst regions in the northern Hemisphere, Elsevier: 85-128.

BISSANTI A., 1966. La dolina Pozzatina del Gargano. Riv. Geogr. It., LXXIII: 312-321.

BOENZI, M. CALDARA and L. PENNETTA, 1991. Alcuni aspetti del rapporto tra l'uomo e l'ambiente carsico in Puglia. Itinerari Speleologici II, 5: 41-51.

BONDESAN A. and MENEGHEL M., 1990. Impact by limestone exploitation in western Lessini Mountains (North-Eastern Italy). Proc. Int. Conf. on Anthropogenic and environmental changes in karst, Czechoslovakia-Hungheria. Studia Carsologica 2, GGU, CSAV: 7-18.

BRUNET R., 1974. Analyse des paysages et sémiologie. L'Espace Géographique, n²: 120-126. 
BURRI E., 1985. Various aspects of the karstic phenomenon in the urbanised areas of Gissi and neighbouring areas (Southern Abruzzo - Italy), Atti del Simposio Internazionale sul Carsismo delle Evaporiti, Le Grotte d'Italia, XII, Bologna pp.: 143-160.

BURRI E., 1987. Lake Fucino (Abruzzo - Central Italy): ancient and recent drainage of a karstic lake. Karst and Man, University of Ljubljana. Study Group on Man's impact in Karst. Proc. Int. Symposium on human influence on Karst, Postojna, Yugoslavia: 19-30.

BURRI E., 1989. L'impatto antropico nell'area di S. Ninfa, in "I Gessi di S. Ninfa - Studio Multidisciplinare di un'area carsica", Memorie dell'Istituto di Speleologia, Università di Bologna, 3, Bologna, pp.: 191-199.

BURRI E., 1991. Storia di un lago: il Fucino in Abruzzo. Terra 10: 42-52.

BURRI E., 1994. Utilizzazione del territorio ed impatto antropico nell'area limitrofa l'abitato di Piertasecca, Memorie Istituto Italiano di Speleologia, Università di Bologna, 5, Bologna, pp.: 165-169.

BURRI E., MASSOLI NOVELLI R., PETITTA M., 1997. Vulnerability of karstic aquifers in Abruzzi (Italy). Two different case studies: Gran Sasso mountain and Fucino Plain, 6th Conference on Limestone Hydrology and Fissured Aquifers (12th Int. Cong. of Speleology), La Chaux de Fonde, Neuchatel, vol. 2, pp.: 201-204.

BURRI E., PETITTA M., 1998. Groundwater drawdown in karstic aquifers due to agricultural activity in the Fucino Plain (Abruzzi, central Italy), Classical Karst Symposium, Postumia (Slavenia), agosto 1997, Acta Carsologica, 27, Ljubljana, pp.: 27-45.

BURRI E., PETITTA M., 1999. Farming and water management in the Fucino Plain (Central Italy) in the last century, Int. Com. on Irrigation and Drainage (ICID), Seven. Cong. Granada, Q. 48- P. 45

CAMUFFO D. and ENZI S., 1994. Cambiamenti climatici negli ultimi 2000 anni. Il Quaternario, 7/1: 257-266.

CASTIGLIONI B., 1991. Some morphometric and environmental aspects of dolines in Berici Hills (Vicenza, Italy). Proceedings of the International Conference on Environmental Changes in Karst Areas. Quaderni del Dipartimento di Geografia 13, Università di Padova, ISSN: $1120-9682,143-156$.

CASTIGLIONI B., 1998. Some notes about landscape evolution in the Trieste Karst. Reading of the topographic maps time series. Acta carsologica XXVII/1: 47-59.

CASTIGLIONI B., 1999. The doline landscape of the Southern Berici Hills (Vicenza Italy). Analysis of the land use evolution in a Karst area. Etudes de géographie physique, Suppl. $\mathrm{n}^{\circ}$ XXVIII, CAGEP, Université de Provence.

CASTIGLIONI B. and SAURO U., 2000. Large collapse dolines in Puglia (Southern Italy): the cases of "Dolina Pozzatina" in the Gargano plateau and of "Puli" in the Murge. Acta Carsologica XXIX/2:83-93.

COTECCHIA V., 1989. Protezione delle risorse idriche pugliesi. C.N.R.: Gruppo Nazionale per la Difesa dalle Catastrofi Idrogeologiche. Linea di Ricerca N. 4, Rapporto 1986 $-1989$.

CUCCHI F. (ed.), 1990. Preliminary map of the impact of man on karstic environments in Italy (map distributed in a few copies). Istituto di Geografia e Oceanografia dell'Università di Messina.

DEFAURE J.J., NEBOIT R. (eds), 1984. La mobilité des paysages méditerranéenes. Hommahe a P. Birot, Revue Géogr. des Pyrénées du Sud-Ouest, Travaux II.

FORTI P., PERNA G. and BURRI E., 1988. Note illustrative della carta dell'impatto del1'uomo sul Karst della Sardegna. A.I.C., Boll. Ass. It. di Cartografia: 72-74, 421-427.

GAMS I., NICOD J. and SAURO U., 1993. Environmental changes and human impact in 
the mediterranean Karst of France, Italy and Dinaric Region. In WILLIAMS P. (ed.), Karst Terrains: Environmental Changes and Human Impact, Catena Supplement 25: 59-98.

GAMS I., 1991. The origin of the term Karst in the time of transition of Karst (Kras) from deforestation to forestation. Proceedings of the International Conference on Environmental Changes in Karst Areas. Quaderni del Dipartimento di Geografia 13, Università di Padova, ISSN: 1120-9682, 1-8.

GRASSI D. and TADOLINI T., 1986. Vulnerability of the karst groundwater circulating in the north-western portion of the carbonate platform of Apulia (Southern Italy). Karst, water, resources, IAHS publ. $\mathrm{n}^{\circ}$ 161: 307-320.

LAURETI L., 1980. L'utilizzazione delle aree carsiche nel Mezzogiorno Italiano (con particolare riferimento ai piani carsici dell'Appennino). Proc. Int. Symposium on utilization of Karst Areas, Tip. Nazionale, Trieste: 197-201.

LAURETI L., SAURO U., TERRANOVA R., BRANDOLINI P., FIRPO M., PIROLA A., PICCAZZO M., ROSSETTI R. and SMIRAGLIA C., 1996. Physical changes in the Mediterranean basin, Boll. Soc. Geogr. It., serie XII, vol. 1: 7-44.

MACALUSO M., 1987. Anthropic impact in the Piano Battaglia Polje (Madonie Mountains, Sicily). Karst and Man, University of Ljubljana, Study Group on Man's impact in Karst. Proc. Int. Symposium on human influence on Karst, Postojna, Yugoslavia: 31-40.

MACALUSO T., RENDA P. and CATANIA G., 1990. Environmental changes in the Trapani Mts. (Sicily). Karst, Proc. Int. Conf. on Anthropogenic and environmental changes in karst, Czechoslovakia-Hungheria. Studia Carsologica 2, GGU, CSAV: 89-98.

MANNELLA, 1987. Il Gargano: ambiente e organizzazione dello spazio rurale. Pubblicazioni del Dipartimento di Scienze Geografiche e Merceologiche, Università degli Studi di Bari, Adriatica Editrice.

MENEGHEL M., 1987. Aspects of man's influence on the Hills of Verona (North-East Italy). Karst and Man, University of Ljubljana. Study Group on Man's impact in Karst. Proc. Int. Symposium on human influence on Karst, Postojna, Yugoslavia, 231-240.

SAURO U., 1987. The impact of man in the karstic environments of the Venetian Prealps. Karst and Man, University of Ljubljana. Study Group on Man's impact in Karst. Proc. Int. Symposium on human influence on Karst, Postojna , Yugoslavia, 241-254.

SAURO U., 1991. A Polygonal karst in Alte Murge (Puglia, Southern Italy). Z. Geomorph. N.F. $35 / 2: 207-223$.

SAURO U., 1993. Human impact on the karst of the Venetian Fore-Alps (Southern Alps, Northern Italy). Environmental Geology 21/3: 115-121.

SAURO U., BONDESAN A., MENEGHEL M. (eds.), 1991. Proceedings of the International Conference on Environmental Changes in Karst Areas. Quaderni del Dipartimento di Geografia 13, Università di Padova ISSN: 1120-9682, Padova.

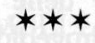

The paper is the result of the cooperation of all the Authors. In particular the the general parts are the result of a common discussion. Paragraphs $n^{\circ} 6$ is written by E. Burri, par. $n^{\circ} 8$ by $B$. Castiglioni, the $n^{\circ} 5$ and 7 by U. Sauro.

This paper result from the research work carried on inside the following programs:

a) MURST 60\% Human impact, environment and morphodinamic in karst area (Prof. U. Sauro);

b) Research Project Padova University: Karst Geo-ecosystems (Prof. U. Sauro);

c) University of L'Aquila - Enviromental Science Dept: Water and Agriculture of

Fucino (supported by ARSSA) (Prof. Ezio Burri). 